\title{
Drug take-overs reflect changing industry
}

Washington. A spate of acquisitions, mergers and sell-offs last week illustrated how drug companies on both sides of the Atlantic are finding ways to survive cost-cutting and consolidation. At least for now, the trend is expected to continue.

Last July, Merck \& Co. started the ball rolling by acquiring Medco Containment Services Inc., one of the largest drug wholesalers in the United States, for about US\$6 billion in stock and cash.

Since then, the shift in the purchasing, financing and delivery of health care in the United States towards more 'managed care' means that pharmaceutical benefit management companies (PBMs) such as Medco have gained in importance.

PBMs, which have become a powerful force in the delivery of health care over the past 5 years, manage insurance claims, ne-

gotiate discounts on drugs with manufacturers on behalf of payers such as large employers and health maintenance organizations, and deal in generic substitutes for brandname drugs. An estimated 60 million Americans now fall under the control of PBMs.

Patricia Lea, an analyst with Vector Securities International, says that the growing importance of PBMs will "force others to integrate vertically or accept secondary positions in the pharmaceutical care game". With non-physicians taking on a more important and influential role in the decisionmaking process, Lea feels that in order to be major global players in the pharmaceutical industry 10 years from now companies will need to align themselves more closely with the likes of PBMs.

This strategy is now being emulated by the British company SmithKline Beecham

\section{Microsoft founder backs gene sequencing}

San Francisco. The founders of the most powerfulUS software company have joined forces with leading biotechnologists and gene sequencers to promote the activities of a small gene sequencing company in Seattle.

William Gates III and Paul Allen, founders of Microsoft Corporation, have invested $\$ 10$ million in Darwin Molecular Corporation, bringing the young company's total funding so far to $\$ 14$ million.

The investment is part of a larger financing which is being sought from the venture capital market and will be announced later this month.

Darwin was founded to develop smallmolecule drugs using the technology of molecular evolu-

tion. This is a procedure that can potentially yield highly specific new drugs by subjecting one generation after another of targeted molecules to a survival test.

\section{Darwin's orig-} inal technologies were developed

\section{IMAGE UNAVAILABLE FOR COPYRIGHT REASONS}

by Stuart Kauffman, one of the company's original founders, and its president. Kauffman still owns the original European patents, and US patent applications, although he has since left the company after a dispute with its current management, and now works as a professor at the Santa Fe Institute in New Mexico, as well as the University of Pennsylvania.

Over the past year, Darwin has linked its work on molecular evolution with DNA sequencing and sophisticated computer analysis, in an effort to use information embedded in the human genome to identify potential targets for drugs against cancer, AIDS and autoimmune disease. It claims to have already created enzymes that may be useful in treating cancer.

Costa Sevastopoulos, a biotechnology venture investor who participated in earlier financing discussions with the company, says that Darwin was in a position to command a high price from Gates and Allen because of its expertise in molecular evolution and the names of scientists already associated with it.

They include Leroy Hood, a member of Darwin's scientific advisory board who played a key role in the founding of the Human Genome Project; Ronald Cape, chairman of the board and former chairman of biotechnology pioneer Cetus Corporation in Emeryville, California; and George Rathmann, chairman of ICOS Corporation in Seattle and chairman emeritus of the highly regarded Amgen Inc. based in Thousand Oaks, California.

Gates is said to have had talks with the company for more than a year before agreeing to invest in it. A biotechnology enthusiast, he has backed several young companies in the industry, including $\$ 5$ million in ICOS, $\$ 5$ million in Seattle-based Targeted Genetics and \$7.5 million in Ligand Pharmaceuticals Inc. in San Diego. Gates also contributed $\$ 12$ million to the University of Washington to lure Hood from the California Institute of Technology to Seattle.

Allen, Gates and Rathmann are to join Darwin's board. Gates and Allen will apply their knowledge of technology and information analysis, as well as their business acumen, to Darwin's medical objectives.

Sally Lehrman plc, which last week announced plans to acquire Diversified Pharmaceutical Services Inc., one of the four largest drug wholesalers in the United States.

The US company, a wholly owned subsidiary of United HealthCare Corporation, handles the pharmaceutical benefits of an estimated 11 million people. SmithKline Beecham is paying US\$2.3 billion for its purchase. As part of the deal, SmithKline has also forged a six-year alliance with United HealthCare. This agreement will provide SmithKline with the exclusive rights to data on 1.6 million members of health maintenance organizations owned by United, enabling it to make valuable comparisons on the cost-effectiveness of treatments.

This new alignment with a PBM is intended to enable the company to compete more effectively in the managed care arena. "Now is the time for us to move beyond the traditional role of selling pharmaceuticals toward a new role as a manager of total health care," said Jan Leschly, chief executive of SmithKline.

Roche Holding Ltd, which is based in Basle in Switzerland, also announced last week that it has made a $\$ 5.3$-billion bid to acquire the ailing Syntex Corporation, a health-care company registered in Panama with headquarters in Palo Alto, California.

The takeover is timely for Syntex. Recent sales figures have been sluggish, in part because the US patent on the company's main product, the non-steroidal anti-inflammatory drug Naprosyn (naproxen), expired last December.

Although Syntex has a dearth of new products for the near term, products in development for the treatment of pain and inflammation, including medicines to treat allergies, cardiovascular and cerebrovascular diseases, are expected to complement Roche's existing drug portfolio.

The deal, which will elevate Roche to fourth position in terms of worldwide sales, also makes sense from a logistical standpoint. Syntex is located near Genentech Inc., a leading US biotechnology company in which Roche acquired a major stake in 1990 for the sum of $\$ 2.1$ billion.

Eastman Kodak Co. has opted for the bold move of getting out of the drug business altogether. George Fisher, Kodak's recently elected chairman, president and chief executive, last week unveiled a new corporate strategy in which Kodak would divest itself of what he described as "non-core businesses". The move will allow Kodak to commit much-needed resources to its imaging businesses, where it is strongest. The company plans to sell off its pharmaceutical and consumer health products subsidiary, Sterling Winthrop Inc., and its clinical diagnostics division, but will retain its health sciences division. Diane Gershon 